\title{
Comparison of corporate governance, strategy, control and performance e valuation systems before and after privatization
}

\author{
Gloria Cuevas-Rodríguez \\ Universidad Pablo de Olvide \\ gcuerod@upo.es \\ Jaime Guerrero-Villegas \\ Universidad Pablo de Olvide \\ jguevil@upo.es \\ Ramón Valle-Cabrera \\ Universidad Pablo de Olvide \\ rvalcab@upo.es
}

\begin{abstract}
The aim of this paper is compare corporate governance and firm strategy before and after privatization. The design of control and performance evaluation systems in the pre and post-privatization periods is compared so that it can be understood in relation to the changes observed at a high corporate level (corporate governance and firm strategy). We carry out various case studies on five privatized Spanish companies. The results support several conclusions. First, the variables that are traditionally related to greater board independence in monitoring do not undergo variation after privatization. Second, the interests of the firms' new ownership bave an impact on firm strategy after privatization. Finally, control and performance evaluation system designs clearly align with firm strategy after privatization.
\end{abstract}

Keywords: Corporate governance, board of directors, privatization, strategy, control system, performance evaluation system. 


\section{Introduction}

The literature suggests that changes in corporate governance due to privatization of a company can affect human resources management practices, such as performance evaluation systems (Cuevas, Alvarez-Dardet and Valle, 2007). Since privatization involves a change in the firm's ownership, one would expect the owners' objectives to be translated into the firm's strategy and the way the firm is managed (Cuervo and Villalonga, 2000).

Although privatization has been widely analyzed, most of the studies have adopted a macroeconomic or political perspective (Zahra, Ireland, Gutierrez and Hitt, 2000). At an organizational level, some studies have emphasized the role of performance evaluation systems or incentives management during privatization (Okpara and Wynn, 2008; Cragg and Dyck, 2000; Schröder, 2003; Giancreco and Peccei, 2005). Other studies have focused on the analysis of the potential changes in strategy once firms have been privatized (Zahra and Hansen, 2000; Cuervo and Villalonga, 2000). However, few comprehensive studies have been made that embrace all the variables together (corporate governance, strategy, control and performance evaluation). One of the few studies that have traced how these changes go back to the essence of privatization - that is, the new ownership of the firm - is by Cuevas et alii (2007), who provide in-depth exploratory evidence on the greater formalization of incentives management when the ownership of a firm changes after privatization.

Our argument is that State-Owned Enterprises (SOEs) and publicly-owned firms are probably managed differently. Consequently, SOEs and publiclyowned companies are expected to adopt different strategies and human resources practices (such as performance evaluation systems) to persuade or discount individuals or coalitions within a company and align their interests to those of the owners.

The aim of this paper, then, is to compare corporate governance and firm strategy before and after privatization. We compare control and performance evaluation systems in the pre- and post-privatization periods, and try to understand them in relation to previous variables (corporate governance and firm strategy). We carry out various case studies on five Spanish privatized companies, and use a variety of data-gathering methods. All of the members of the top management teams were interviewed not just the Chief Executive Officer (CEO). 


\section{Literature review}

Agency theory assumes the existence of interest conflict between principals (owners) and agents (managers), who have different utility functions (Jensen and Meckling, 1976). In this theoretical framework, the corporation's board of directors is legally responsible for overseeing the performance of managers on behalf of owners' interests. Nevertheless, this monitoring function exercised by the board is expected to be different in SOEs and public companies.

In SOEs, multiple social and political pressures distract managers' attention from maximizing profits (Rourke, 1984). Besides, the organization's obligations go beyond shareholders, and liaise with other interest groups (stakeholders) connected to the organization, such as the employees, suppliers or clients. In agency theory, these connections are regarded as mere instrumental relationships the objective of which is to maximize profits (Donaldson and Preston, 1995). The role of the company's management is to balance the interests of the various groups involved, this being the only way to ensure the survival of the company. However, the existence of multiple interests, characteristic of SOEs, could be translated into 'fuzzy' objectives that make it difficult to monitor the board's function of evaluating managers' performance. In fact, Nestor (2005) suggests that managerial decisions in SOEs are often the result of political rather than performance-oriented imperatives. Boards are either political appointees or civil servants and so are managers. Moreover, the disciplinary power of capital markets is absent in SOEs, which makes the problem of manager control worse.

In contrast, publicly held companies are presumed to have just one principal: namely, the shareholders. These may be a diverse group, but the divergence of interests between principals and agents is reduced through the existence of (1) a market of ownership rights that enables the owners to sell if they are not satisfied with managerial performance; (2) the threat of takeover; and (3) the threat of bankruptcy. Besides, board members are elected on the basis of their business capabilities. So, privatization usually involves depoliticizing the decision-making process and company governance (Nestor, 2005). Specifically, after privatization, the company and its management are held to the forces of the market. In this new context, in which the company must survive and be successful, managers begin to develop strategies based on their analysis of the industry and the conditions of the market (Zahra et alii, 2000). Strategies of diversification and internationalization are usually common factors once SOEs have been privatized (Zahra, Neubaum and Huse, 2000).

Agency theory stresses that privatization changes the board's way of overseeing the CEO and encourages formal performance evaluation (Young, Stedham and 
Beekun, 2000). Although corporate boards are typically not required by law to establish formal management control over the CEO's performance, some authors agree that a formal process for evaluating managers' performance is a fundamental feature of corporate governance (Tosi and Gomez-Mejia, 1994). Alternatively, compensation design could be a contracting mechanism for aligning the interest of managers (agents) with the interest of owners (principals) (Eisenhardt, 1989; Fama and Jensen, 1983).

Agency theory's argument that the board exercises greater control is linked to the fact that after privatization 'core' shareholders will hold a sufficiently high proportion of a company's shares to justify their combining ownership with some degree of board control, in contrast to the dispersed shareholders of SOEs (Shleifer and Vishny, 1986). In fact, Michael and Pearce (2004) have suggested that constraints imposed as a result of shareholder pressure on the board of directors could be regarded as a valuable solution to the agency problem, as they can actively commit managers not to undertake certain tasks.

Based on the previous discussion, our proposition is as follows:

Greater board control of firm management and a clearer definition of firm strategy after privatization will imply the adoption of a more formal performance evaluation system.

\section{Research methodology}

In order to compare corporate governance, strategy and performance evaluation systems before and after privatization, we employ a multi-case research method.

In line with Yin's (1994) suggestions, the five cases that this study examines are not an arbitrary selection. They include all possible combinations of three control variables: namely, (1) the industrial sector (because companies should belong to different industries), (2) company size, and (3) privatization methods. Two additional restrictions in this case study framework are that the companies under examination are large enough to guarantee the existence of formal corporate governance and were privatized after 1996 for two reasons:

1. The last wave of privatizations in Spain began after 1996 with the "Modernization Program of the Public Sector", which encourages the privatization of efficient SOEs and focuses on non-efficient SOEs to prepare them for privatization.

2. This study uses questionnaires by which the members of the top management team of each company provide information about the five years before and after privatization. Thus, the managers in this study 
have enough history and experience within the company to compare the pre- and post-privatization periods.

Our primary data was collected from 18 interviews with top management teams (5 managers were interviewed in Endesa, 4 in Repsol, 2 in Enagas, 3 in Iberia and 4 in Retevision). Although data was mainly collected from questionnaires sent to top managers, triangulation was achieved using other sources of information such as Annual Accounting Statements, the Spanish Central Bank's database or SEPI reports (Spanish Society of State-Owned Companies). The whole set of data covers ten years (the five years before and after privatization) although the period under consideration varies according to the time each company was privatized.

The data collection and analyses were highly iterative processes in this research (Yin, 1994). Staggering the volume of data in this study was possible by focusing on three dimensions or variables: (1) the company's governance structure, (2) company strategies, and (3) manager control and performance evaluation systems.

For our first variable, that is, the company's governance structure, we used the specific measurements reported in (Coles et alii, 2001; Hsu, 2010): (1) separate positions for the $\mathrm{CEO}$ and the chairperson of the board, (2) board composition, and (3) ownership structure and concentration.

For the second variable, company strategies, we use Dess and Davis' (1980) measures. As these authors state, classifying firm strategies into one generic Porter's typology (cost leadership, differentiation and focus strategy) is a valuable tool, but it also implies an atomistic view of strategy because each firm is unique in all respects. Alternatively, Dess and Davis (1980) propose a new view that recognizes commonalities among firms as far as the higher or lower importance of a set of strategic choices is concerned. This notion of strategic choices helps track the role that corporate governance (and firm ownership) plays in pursuing a specific purpose, making decisions and adopting competitive methods, all of them inherent in the concept of strategy (White \& Hammermesh, 1981, pp. 216). Thus, managers had to score a total of 20 items (strategic choices) using a five-point Likert scale on which 1 implied a low level of relevance of the strategic competitive item and 5 indicated high relevance. As with other variables, each item refers to both pre- and post-privatization periods.

Finally, the control system was measured applying the typology proposed by Whitley (1999), attending to the following dimensions: degree of formalization of the control system, degree of exerted control, commitment and participation of the employees in the control activity, and the scope of the information used. In 
addition, we used measurements based on the work of Carpenter and Westphal (2001) to determine the degree of control exerted by the board of directors on top managers. And for managers' performance evaluation systems, we used Scott and Tiessen's measurement (1999) to group them in three categories: financial, non-financial and other performance measures.

\subsection{The case studies}

Retevisión. The privatization of Retevisión (telecommunications sector) was initiated in 1997 when the State called for a PO of the sale of $60 \%$ of the company's stock. This brought a capital increase of $10 \%$ to be covered by the investors, while the State's participation was reduced to $30 \%$. In this first phase of the company's privatization, two of the major players in terms of industrial groups in the country entered the company as shareholders (the public utility companies Endesa and Union Fenosa), as well as an international operator (Telecom Italia) and various financial institutions (Bilbao Bizkaia Kutxa and Unicaja, amongst others). A new chairman took on the role of running the company, and stayed with them until 2000.

The liberalization of the sector reached its highest point in 1998 with the passing of the General Law on Telecommunications. To sum up, the sector's liberalization boiled down to a) a reduction in the prices of services offered as a result of competition, as well as other effects; b) market growth, and c) a rise in the number of employees in the sector, either directly or created by the knock-on effect. In 1998, the company had sales of 364.2 million euros, an increase of $54 \%$ on the previous year, and the number of employees increased to $67 \%$ in the same period (1,286 in 1997 and 1,909 in 1998).

The privatization of $30 \%$ of the company's stock took place in 1999. This transferal of $30 \%$ of Retevisión assets was based on the strict conditions of the legal framework under which the first privatization operation took place.

Privatization sparked the strategic orientation of Retevisión as a major player in the telecommunications market. Retevision also changed the way people behaved in the sector, with a clear, flexible and open policy. The company's strategy created competition in the sector, which led to openness in the market, lower prices for basic services and the increased competitiveness of other companies.

Enagas: The National Gas Company (Enagas) was created in 1972 with the aim of creating a network of gas conducts throughout the Spanish Peninsula, and was entirely owned by the State through the National Industry Institute (I.N.I). 
In 1991 an event took place that had a resounding effect on the gas sector in Spain. The creation of a new company named Gas Natural SDG brought about the restructuring of the distribution sector and better coordination with Enagas in the division of labor.

In terms of the structure of the company, the most important event took place in 1993: the signing of an intention protocol for the complete integration of the Spanish gas sector. The aim was for Gas Natural SDG to acquire most of the control of Enagas. To simplify the characteristics of this complex operation, it was agreed that both companies would have, from that moment on, the same CEO. Based on this agreement, the negotiations concluded with Gas Natural SDG purchasing 91\% of the Enagas stock in 1994 and acquiring the remaining $9 \%$ in 1998 .

The law passed on 6th June 2000 laid out the plans for completing the process of liberalization in the gas sector. The Ministerial Order of February 2002 established the specific framework for tariff implementation and payment rights necessary to fund the modernization of the gas network, transport, storage and distribution of natural gas. This would enable the system to be run in a proper and structured way.

In 2003 the liberalization of commercialization in the gas sector was concluded successfully in such a way that from January onwards of this same year any customer could choose their natural gas supplier. Finally, on the 26th June 2003, a European Directive on gas was published, which regulated the liberalization process in the internal European gas market.

In 2002 the company completed its flotation on the stock exchange and began its journey on the stock market with a commitment to the highest quality practices of corporate government, based on the pillars of openness, independence and the defense of the shareholders rights.

Endesa: The third company chosen as a case study was Endesa, which belonged to a sector with considerable economic and technical significance in Spain: electricity. The structure of the company's ownership had been changed during a ten-year privatization program via four public offerings (POs) in 1988, 1994, 1997 , and 1998, with the State's holding in the company being reduced to $75.6 \%$, $66.89 \%, 25 \%$ and $3 \%$, respectively.

In the group of main shareholders in Endesa there were four major financial institutions: the banks, BSCH (3\%), BBVA (2.7\%), and the building societies La Caixa (2.5\%) and Caja Madrid (4.2\%). Also, during the study period the change produced in the industrial sector caused knock-on changes in the 
strategy followed by the company, partly as a response to the new competitive environment.

The passing of the Basic Law for the National Electrical Sector (LOSEN) in 1994 and the Electrical Protocol of 1996 introduced measures such as the reduction of entry barriers into the generating business or greater facilities for the sale of electricity to third parties, which opened up the market to competition. The new features of the electrical sector helped the companies to operate more efficiently and focused on customer services.

In the middle of the 1990s (1994-1998), and coinciding with the successive POs which led to the privatization of Endesa, the company strengthened its competitive position in the electrical sector (characterized by a gradual liberalization), with the diversification of other sectors that experienced growth and internationalization. The spectacular increase in market share from 1990 onwards, and the number of Endesa customers reflect, amongst other factors, the process of business expansion at both a national and an international level.

Iberia: Iberia is one the major European network operators of air travel for passengers and cargo, although it is also involved in such related business activities as the maintenance and distribution of aircraft for both Iberia and other airlines.

In the privatization of Iberia there were three phases: (1) direct sales, in which the "industrial partners" were selected, (2) direct sales, in which the "institutional partners" were selected, and (3) a final phase by which privatization was completed through POs. These three phases involved the transferral of $10 \%, 30 \%$ and $53.7 \%$ of the company's stock capital belonging to SEPI (State Company for Industrial Participations). The rest of the stock remained in the hands of the company's employees.

With respect to the first phase which took place in February 1999, a framework agreement was reached with American Airlines, British Airways, Iberia and SEPI for which NEWCO (a company controlled 90\% by British Airways and $10 \%$ by American Airlines) agreed to purchase $10 \%$ of Iberia's stock. This trading operation was the first phase of the company's privatization scheme.

Also in 1999, 30\% of Iberia's stock was transferred, with $10 \%$ of the shares going to Caja Madrid, 7.3\% to the BBVA, 6.7\% to Logista Aeroportuaria S.A, and $3 \%$ each to the Corte Inglés and the Ahorro Corporation S.A.

Finally, in 2001, in the third phase of the operation, the board of directors of SEPI sold $53.7 \%$ of Iberia's stock. In this year, the company increased its income to 4,581 million euros and employed 25,000 workers.

In the year 2000 Iberia initiated a new management plan, which was in force until 2003. The aim of the plan was mainly to consolidate the company in the 
market, improve its financial and operating profitability ratios, and increase the shareholder value. The company improved its competitive positions in Europe (share quote, 34.5\%) and maintained its leadership in the domestic market (share quote, 70.4\%), and the intercontinental market (share quote, $15.1 \%$ in Europe-Latin America air traffic, where the company was the market leader with a share quote of $44.5 \%$ in Spain-Latin American air traffic). As for the governing bodies of the company, it should be pointed out that a new CEO was appointed to drive Iberia's privatization. He remained in the position from 1996 to 2003.

Repsol: The fifth company chosen in our multi-case study belongs to the fuel sector, which has been strictly regulated in Spain and has operated as a state monopoly since 1927. In fact, the liberalizing legal framework that now affects the entire sector was not established until 1998 when the Law on Hydrocarbons in Spain was passed. This meant the complete opening of the fuel market and the regulation of all activities involving gas. The maximum sale prices for fuel were done away with and the natural gas sector was liberalized at a greater pace than the established European average. Privatization was carried out over a period of eight years and via such financial mechanisms as direct sales, bond issues and POs. The privatization of the whole company concluded in 1997.

The process had started in 1989 when $26 \%$ of the company's stock was put up for sale. In 1992 and 1993 the privatization process continued via a comprehensive share offer entirely for wholesale investors and institutions, which reduced the State's participation in the company to 30\%. In 1995 and 1996, successive POs took place, this time addressed to retailers and small-scale investors. This had the effect of reducing the State's stake in the company to $10 \%$ with the other $90 \%$ in the hands of a diverse group of private and institutional investors. In 1997, the process of privatization for the company was completed with the sale (also by PO) of the remaining $10 \%$ that the State owned.

The company adopted a hitherto unseen strategy of international expansion during its fourth phase of privatization in 1996. Its strategic priority was to initiate its expansion in Latin America as a worldwide energy company.

In 1999, the most important event in Repsol's history took place when the firm was the successful bidder for a 14.99\% stake in YPF, the largest public petrol and gas company in Latin America at an auction called by the Government of Argentina. With the acquisition of YPF, the company was transformed into a major player in the energy field in Latin America and Spain, and advanced notably towards their strategic aims. Thus, during 1999, net profits of the company surpassed 1,000 million Euros, which reflected a rise of $16 \%$ on the previous year. By the end of 1999 , the number of employees had risen to 33,884 . 
In the year 2000, the process of integration between Repsol and YPF was completed, and created the need to rethink some processes and policies regarding decision making in the company, which in turn gave way to a new management model.

With respect to corporate governance, the CEO was the same from 1987 to 1996. In June 1996, when the Conservative Popular Party came to power, a new CEO was appointed, who would stay in the post until 2004.

\section{Findings}

\subsection{A general overview of the five case studies and their socio- economic and political context}

Now that the five case studies have been described, some aspects of the political and socio-economic context in which the privatizations occurred should be discussed. They took place in the period beginning in 1996, with the coming to power of the Popular Party, when there was an obvious change in the approach to privatization. The so-called Privatization Advisory Council, a body to inform the proposed sale of public enterprises and to verify compliance with the principles of openness, transparency and free competition, was created. Each operation had to be informed by the Council prior to taking the decision to sell. Also, a Privatization Plan, which set out the objectives, methods and pace of operations, was also created. In June 1996, an agreement by the Spanish cabinet on the foundations of the Modernization Program of the Business Public sector (known as the Privatization Program) was approved. This meant a new orientation of the public business sector, with a redistribution of functions in the public and private sectors of the economy. This reassignment was embodied in the withdrawal of the public sector from virtually all business activity.

The privatization program classified public enterprises into four groups. The first group were companies to be privatized immediately because of their high profitability and attractiveness to potential investors. Among these companies, known as "the jewels of the crown", were Enagas, Endesa and Repsol. The second group was composed of companies in sectors that were about to be reorganized, but were important here because substantial income could be obtained by their sale. Retevision was in this group. The third group was composed of those of companies that required restructuring or improvements prior to sale. This group included Iberia. And the final group was made up of companies that were undergoing some kind of restructuring, but which would not be able to be privatized in the short term for strategic or social reasons. 
As can be seen, all state-owned companies were considered amenable to privatization, regardless of their economic situation. Therefore, the privatization policy in this period can be qualified as mass privatization, and reflects a new conception of the role of the public sector in the economy. This is what radically differentiates this period from previous ones.

As some authors have suggested (Yoshikawa and Phan, 2005), it is important to contextualize research to have a comprehensive understanding not only of the political and socio-economic circumstances but also of the idiosyncrasy of a specific country. A difference in national context can, for example, limit the extent to which standard agency theory assumptions about investor risk preferences, managerial behavior and board functions can be applied (Yoshikawa and Phan, 2005). In this regard, Aguilera (2005, pp. 198) suggests that Spain, along with Italy and to some extent France, follows the so-called Latin model, which is characterized by strong state intervention, weak labor participation at the company level, and concentrated firm ownership. Overall, according to Aguilera (2005), the Spanish corporate governance scene is composed of newly privatized firms owned by core investors (some of whom are foreign), a weak market for corporate control, and sporadic use of Anglo-Saxon practices, although certain reforms have been undertaken to increase the transparency and accountability of firms, as well as the efficiency of boards of directors.

Privatized firms are expected to improve control mechanisms and align owner and manager goals better by adopting a more formal performance evaluation system. Although these issues are expected from an agency theory perspective, we should acknowledge the idiosyncrasy of Spanish corporate governance and the importance of context to understand the corporate governance of firms before and after privatization.

The various case studies show that the ownership structures during the study period were conditioned by privatization processes and the evolution of regulation and liberalization in the sectors. However, they confirm that whatever privatization method was used (direct sales, POs, bond issues, etc.), the public sector has been replaced not by an anonymous mass of small shareholders but rather groups (the so-called "hard-core"). Through these hard-core groups, the State privatized significant amounts of shares and gave them to prominent entities with the guarantee that they would not be transferred, thus giving some stability to the composition of capital.It should be pointed out that the Spanish government temporarily granted "golden shares" to three of the companies analyzed (Iberia, Repsol and Endesa, which expired in 2006 for Iberia and Repsol, and 2008 for Endesa). In this way the State had the right to veto or authorize certain strategic decisions, and the chance to block foreign shareholdings. 
Finally, the comparative analysis of our five studies seems to show that firms reorganize their strategies once they are in private hands. This fits with agency theory, which supports the greater discretion of the board of directors after privatization to adopt strategic decisions based on market analysis and industrial conditions. In general terms, then, it seems that the strategies of the companies analyzed favored market growth after privatization and were characterized by expansion and diversification. Although we cannot assure that these strategies are more prospective than defensive in nature, we observed special attention to efficiency and the reduction of operational costs after privatization.

Below, the firm governance structure, strategic orientation and performance evaluation systems are compared using data from the five case studies before and after privatization.

\subsection{Firm governance structure}

We are going to analyze data on the three factors used to measure the board's level of supervision (Young et alii, 2000): that is, (1) separate positions for the CEO and the chairperson of the board, (2) the composition of the board and, (3) the structure/concentration of ownership.

A dichotomous variable was used for the first factor with a value of 1 when the positions of CEO and chairman were held by the same individual, and a value of 0 when they were held by different individuals. We observed that one of these five companies had different individuals for the two positions after privatization. Unexpectedly, then, no changes were observed in four out of the five companies, which entrusted the two positions to the same individual before and after privatization. Agency theory predicts that the positions of CEO and chairman should be occupied by different individuals after privatization so that the board of directors can have greater control over managers.

To analyze the composition of the board, we classified the members according to Baysinger and Butler (1985), Kim (2007), Heracleous (2001), and Rutherford and Buchholtz (2007). Those members with a contractual relationship in the company were classified as insiders. Those members who did not hold professional positions in the company and were named only as members of the board were defined as outsiders.

Our analysis does not show a clear change after privatization. In the preprivatization period, outsiders represented an average of $79 \%$ whereas postprivatization this percentage was $88 \%$. And contrary to theoretical expectations, one of the companies had a lower percentage of outsiders after privatization $(83 \%)$ than in the period before privatization (92\%). With regards to the year of 
privatization, there was no clear tendency to increase the percentage of external advisors in comparison to the pre- and post-privatization periods. So this cannot be viewed as a positive step to create a more diverse and independent board. In this regard, Cabeza and Gomez's (2007) results also show a lack of independence of the Spanish boards of directors after privatization.

One issue which must be highlighted regarding the composition of the board is the turnover of directors. More specifically, three of the companies analyzed show an increase in the rotation on their boards, going from .08 before privatization to .24 after. On the other hand, in two of the five companies studied, rotation decreased considerably, going from .52 before privatization to .07 afterwards. This is partly due to the high level of rotation observed in the years leading up to the privatization of these companies, which may be interpreted as preparation for the company going into private hands.

Finally, we analyzed the ownership structure of the companies using the percentage of corporate stock in the hands of major shareholders (that is, those who own more than $5 \%$ of the stock) (ICON) (Tosi and Gomez-Mejia, 1989). Table 1 shows significant shareholders (ICON) for each company both before and after privatization. Figure 1 clearly shows a high concentration of capital before privatization. This concentration is reasonable because, before privatization, all or most of the shares in these companies are the property of the state. After privatization, although the concentration of capital generally falls, the average percentage in the hands of important shareholders is still high, and reaches almost $47 \%$.

Table 1: Stock in the hands of major shareholders (\%) (ICON)

\begin{tabular}{|r|r|r|r|r|r|r|}
\cline { 2 - 7 } \multicolumn{1}{c|}{} & Retevision & Enagas & Endesa & Iberia & Repsol & Average \\
\hline Before privatization & 100.00 & 100.00 & 66.95 & 92.18 & 76.97 & 87.22 \\
\hline After privatization & 74.22 & 81.51 & 15.22 & 39.56 & 23.53 & 46.81 \\
\hline
\end{tabular}


Figure 1: Evolution of stock controlled by major shareholders (ICON)

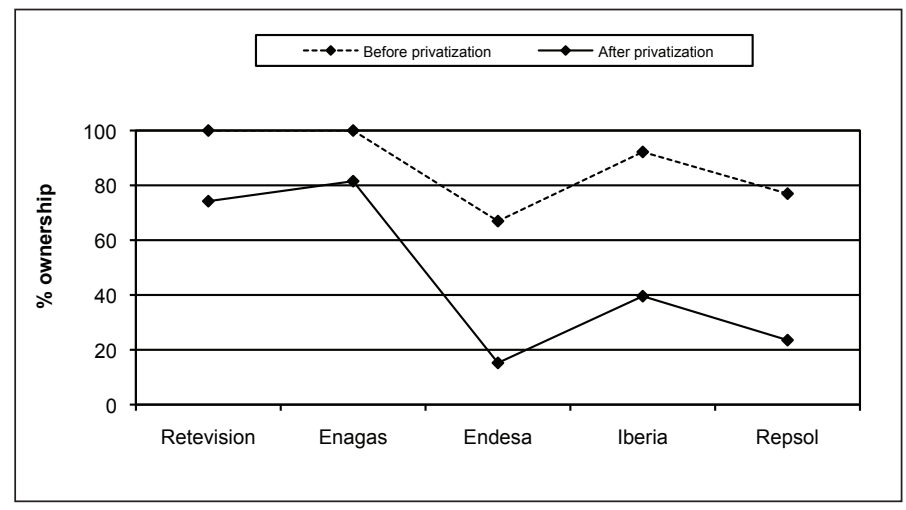

One of the characteristics of corporate governance in the continental European model

is the presence of major shareholders in the company stock (financial institutions, family groups and other companies), who usually exert considerable control over the company (Fernández and Arrondo, 2005). In countries like Spain, the government actively promoted the creation of stable investors, largely banks, after the privatization program (Tribo, Berrone and Surroca, 2007). This was particularly the case between 1996 and 2003.

In our study, and as was expected from a theoretical viewpoint, we observe the existence of 'core' shareholders (such as financial institutions) who hold a sufficiently high proportion of a company's shares. This seems to imply some degree of control over the board, in contrast to the dispersed shareholding and 'free-rider problem' of SOEs. Yet there is no agreement or clear empirical evidence on what proportion is sufficiently high'. Tosi and Gomez-Mejia (1989) suggest that $5 \%$ could be considered enough to allow an owner to sway or veto strategic decisions. Our findings suggest that there were financial institutions with at least $5 \%$ of capital that was privatized in four out of the five cases (see table 2). With the exception of the first company, in which no financial institution is a shareholder, three of the companies have two financial institutions holding $10 \%$, $17.75 \%$ and $15.7 \%$ of the capital. 
Table 2: Financial institutions with a stock participation of over 5\% after the privatization of the companies

\begin{tabular}{|c|c|c|c|}
\cline { 2 - 4 } \multicolumn{1}{c|}{} & $\begin{array}{c}\text { Number of } \\
\text { financial } \\
\text { institutions }\end{array}$ & Participation in the capital & $\begin{array}{c}\text { Total } \\
\text { participation }\end{array}$ \\
\hline Retevision & 0 & Bancaja (5\%); Cajatsur (5\%); \\
Cam (5\%) & $0 \%$ \\
\hline Endesa & 2 & Caja Madrid (5\%); Caixa (5\%) & $15 \%$ \\
\hline Iberia & 2 & Caja Madrid (9.84); BBVA (7.91\%) & $10 \%$ \\
\hline Repsol & 2 & Caixa (10.7\%); BBVA (5\%) & $17.75 \%$ \\
\hline Average & \multicolumn{3}{|r}{} \\
\hline
\end{tabular}

These results are similar to those obtained recently by Cabeza and Gomez (2007), who showed that financial institutions are major shareholders in $75 \%$ of Spanish privatized companies.

Generally, no matter what method was used for the privatization process or how long it took, institutional groups attend to make up the stable core of shareholders committed to the proper running of the company. Through these hard-core groups, the State privatizes significant amounts of shares in order to grant them to prominent entities, with the guarantee that these shares will not be transferred. In this way, the composition of the capital is guaranteed a certain stability.

\subsection{Strategic competitive factors}

The description and contextualization of the five case studies shows that in some cases privatized companies led the process of liberalization in the sectors in which they operated, thus allowing for the creation of market competition. This was the case of Retevision, when they broke the monopoly that Telefónica had over Spain. In the natural gas sector, the beginning of the liberalization process made Enagas an essential vehicle for the entry of new operators into the supply market.

In general, the strategies followed by privatized companies have favored market growth and have been characterized by the expansion and diversification of new sectors. This is the case of Repsol and Endesa. For the latter, the measures taken to open up to competition in the electrical sector required the company to operate more efficiently and with a management plan better geared towards quality control and customer services. 
In general terms, bureaucracy and pressure from stakeholders mean that SOEs have greater organizational inertia. These were driving forces behind the reduction of incentives to produce change. So the companies' resources needed to be modified to make them more competitive (Romero 2006). SOEs tend to be more conservative and have a defensive attitude towards the market (Tan and Litschert, 1994).

Following privatization, companies and their management were limited by market forces, which created a new scenario in which they had survive and be successful. In this context, the board of directors began to plan and develop strategies based on the analysis of the industry and market conditions (Zahra et alii, 2000).

Privatization creates a favorable environment for the companies to make foreign investments, particularly in technology transfer and product and marketing techniques (Zahra et alii, 2000). Private property prompts directors to take riskier decisions due to innovations in products and organization (Zahra and Hansen, 2000). Also, following privatization, the board of directors have more freedom to redefine the organizational targets of their key shareholders (Yarrow, 1986).

We shall now move on to look at various factors regarding competition. Table 3 shows the average scores of responses given by top management teams to twenty questions on their company's strategic orientation. The comparison of scores assigned to the pre- and post-privatization periods shows that the weight or relative importance of the different strategic factors is quite similar in both periods. There is no change in the strategic pattern of the company. However, despite having the same strategic orientation, the companies strengthened all their strategic factors after privatization. Scores on all items (except item 13) were systematically higher after privatization (see figure 2). This was corroborated when the analysis was reproduced individually for each company. It should also be noted that the standard deviations of 13 of the 20 items were lower after privatization. This suggests a tendency to value strategic items similarly and implies that companies converge toward a similar weighting of competitiveness with respect to other strategic factors. 
Table 3: Strategic competitive factors before and after privatization (with standard deviations in parentheses)

\begin{tabular}{|c|c|c|c|c|}
\hline & \multirow{2}{*}{ Before } & \multirow{2}{*}{ After } & \multicolumn{2}{|c|}{ Wilcoxon test } \\
\hline & & & $Z$ & $p$-value \\
\hline 1. New product development & $\begin{array}{l}3.00 \\
(.71) \\
\end{array}$ & $\begin{array}{l}4.30 \\
(.82) \\
\end{array}$ & -1.62 & .10 \\
\hline 2. Customer services & $\begin{array}{l}2.67 \\
(.62) \\
\end{array}$ & $\begin{array}{l}4.70 \\
(.41)\end{array}$ & -2.02 & .04 \\
\hline 3. Continuous effort to obtain cost reductions & $\begin{array}{l}2.93 \\
(1.36)\end{array}$ & $\begin{array}{l}4.75 \\
(.25)\end{array}$ & -2.02 & .04 \\
\hline 4. Quality control on products/services & $\begin{array}{c}3.80 \\
(1.10)\end{array}$ & $\begin{array}{l}4.57 \\
(.31)\end{array}$ & -1.83 & .07 \\
\hline 5. Training and experience of buman resources & $\begin{array}{l}3.53 \\
(.51) \\
\end{array}$ & $\begin{array}{l}4.35 \\
(.49) \\
\end{array}$ & -1.84 & .07 \\
\hline 6. Competitive prices & $\begin{array}{l}2.67 \\
(.94)\end{array}$ & $\begin{array}{c}4.07 \\
(1.20)\end{array}$ & -1.83 & .07 \\
\hline 7. Wide range of products/services & $\begin{array}{l}2.27 \\
(.83)\end{array}$ & $\begin{array}{l}3.35 \\
(.89)\end{array}$ & -1.21 & .22 \\
\hline 8. Development/improvement of old products/services & $\begin{array}{c}3.00 \\
(1.22)\end{array}$ & $\begin{array}{l}4.08 \\
(.64)\end{array}$ & -1.83 & .07 \\
\hline 9. Brand & $\begin{array}{c}3.00 \\
(1.22)\end{array}$ & $\begin{array}{l}4.05 \\
(.72)\end{array}$ & -1.46 & .14 \\
\hline 10. Innovation in marketing techniques and methods & $\begin{array}{c}2.33 \\
(1.31) \\
\end{array}$ & $\begin{array}{l}3.63 \\
(.74) \\
\end{array}$ & -1.35 & .18 \\
\hline 11. Distribution channel control & $\begin{array}{c}2.44 \\
(1.26) \\
\end{array}$ & $\begin{array}{c}3.68 \\
(1.59) \\
\end{array}$ & -1.60 & .11 \\
\hline 12. Raw materials for products/services & $\begin{array}{c}4.00 \\
(1.00)\end{array}$ & $\begin{array}{l}4.40 \\
(.55)\end{array}$ & -1.00 & .32 \\
\hline 13. Minimization of external financial support & $\begin{array}{l}2.60 \\
(.55) \\
\end{array}$ & $\begin{array}{l}2.35 \\
(.60)\end{array}$ & -.74 & .46 \\
\hline 14. Specialization in geographical segments & $\begin{array}{c}2.53 \\
(1.50) \\
\end{array}$ & $\begin{array}{c}3.22 \\
(1.33) \\
\end{array}$ & -.67 & .50 \\
\hline 15. Ability to make specific products/services & $\begin{array}{l}3.00 \\
(.71)\end{array}$ & $\begin{array}{l}3.75 \\
(.50)\end{array}$ & -1.84 & .07 \\
\hline 16. Products/services with high price in the market & $\begin{array}{l}2.40 \\
(.89) \\
\end{array}$ & $\begin{array}{c}2.85 \\
(1.24)\end{array}$ & -1.34 & .18 \\
\hline $\begin{array}{l}\text { 17. Promotion and marketing in the media by other } \\
\text { companies in the sector }\end{array}$ & $\begin{array}{l}2.33 \\
(.85)\end{array}$ & $\begin{array}{l}3.18 \\
(1.15)\end{array}$ & -1.46 & .14 \\
\hline 18. Reputation within the sector & $\begin{array}{l}3.53 \\
(.65)\end{array}$ & $\begin{array}{l}4.42 \\
(.28)\end{array}$ & -1.84 & .07 \\
\hline 19. Foresight of market growth & $\begin{array}{c}3.47 \\
(1.12) \\
\end{array}$ & $\begin{array}{r}4.60 \\
(.45) \\
\end{array}$ & -1.83 & .07 \\
\hline 20. Process innovation in products/services & $\begin{array}{c}3.13 \\
(1.12) \\
\end{array}$ & $\begin{array}{l}4.18 \\
(.83) \\
\end{array}$ & -1.60 & .11 \\
\hline
\end{tabular}


Figure 2: Strategic competitive factors before and after privatization

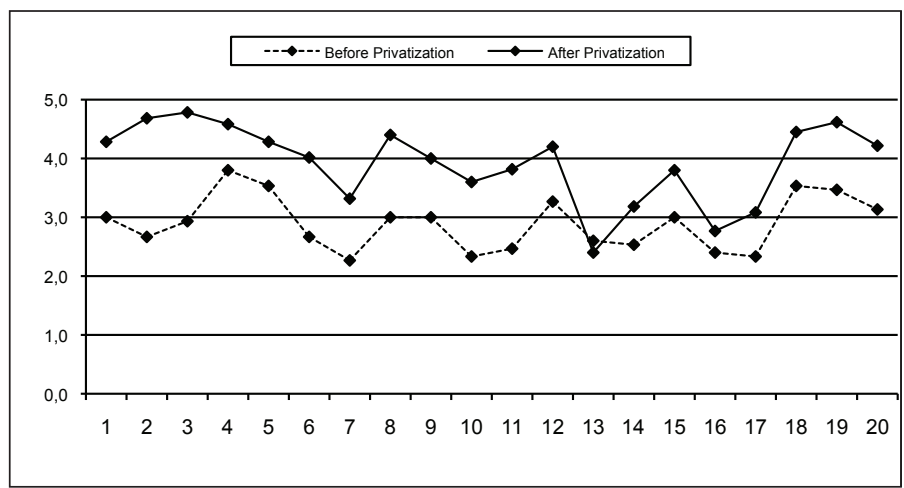

A Wilcoxon non-parametric test (Siegel and Castellan, 1988) was applied to test the statistically significant differences between scores for strategic factors before and after privatization. As in the signal test, results showed statistically significant differences $(p=.00)$. These results were corroborated with the $t$-student test, which also rejected the null hypothesis of similarity among average scores before and after privatization $(p=.00)$.

Although company strategies followed a similar pattern before and after privatization, there were differences in such items as customer service (item 2), cost reduction (item 3), quality control for products/services (item 4), training and experience building for human resources (item 5), competitive prices (item 6), the development and improvement of products and services (item 8), the ability to create specific products and services (item 15), reputation within the sector (item 18) and foresight regarding market growth (item 19). These results make sense because marketing, efficiency and product innovation are key factors for competition in the market, once the company is privatized (Zhara et alii, 2000). Table 3 shows the results of the Wilcoxon non-parametric test for each item.

The only exception to this tendency in strategic factors and with a lower value after privatization is item 13 , which refers to the use of external financing. The results show that the minimization of this type of financing is no longer such a main aim once the company is privatized. 


\subsection{Control system}

Table 4 displays the averages of all the companies for each of the items used to measure the control system. The responses given by managers in the questionnaire were grouped for the periods before and after privatization.

\section{Table 4: Control system before and after privatization (with standard deviations in parentheses)}

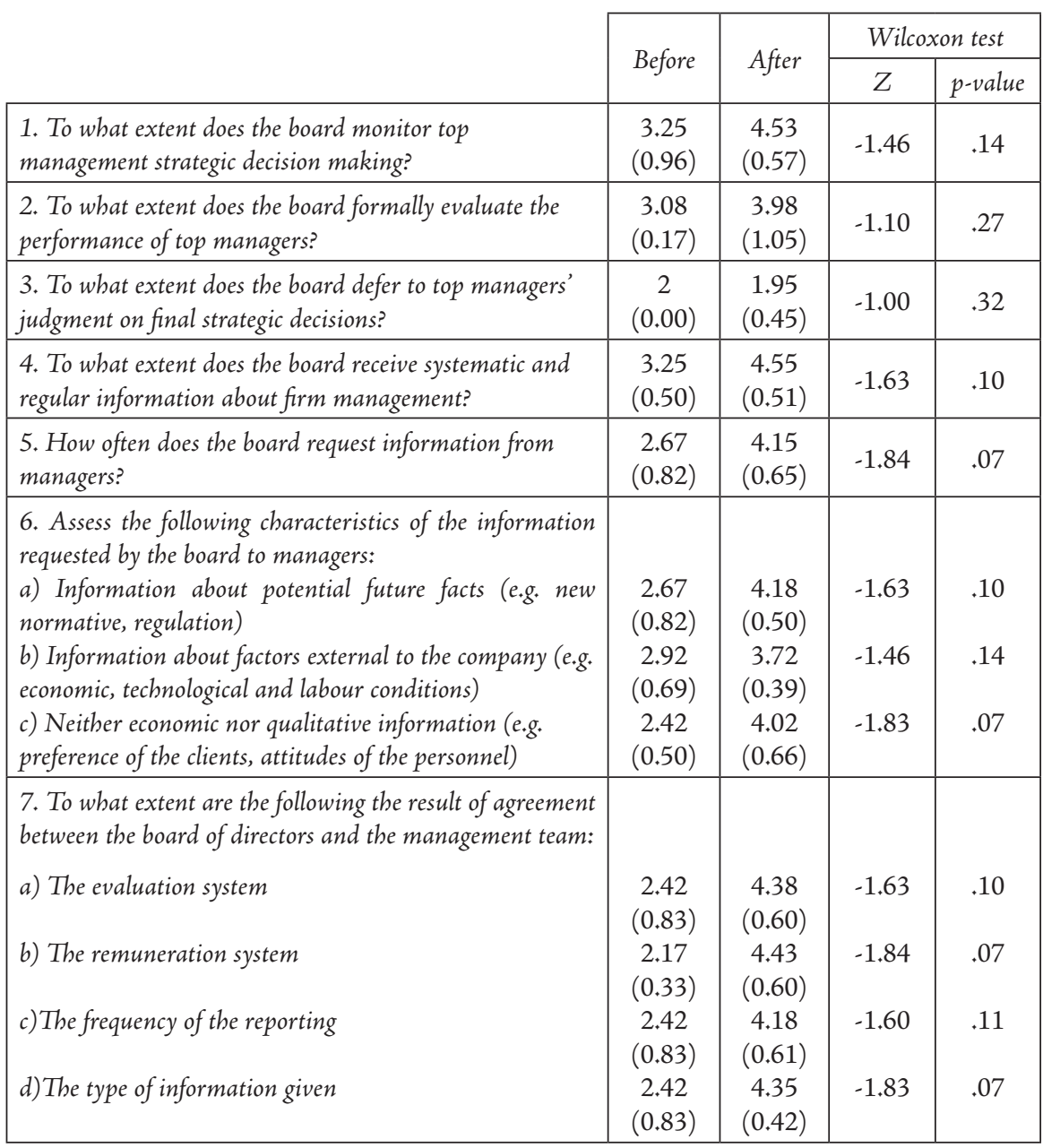

Figure 3 shows clear differences in the averages for all the representative items of the control applied by the board of directors in both periods (before and after privatization), with the exception of item 3 . The value of this item (value= 2) reflects little difference in the conception of management of the two bodies (board of directors and top management team). 
Figure 3: Control system in the pre- and post-privatization period

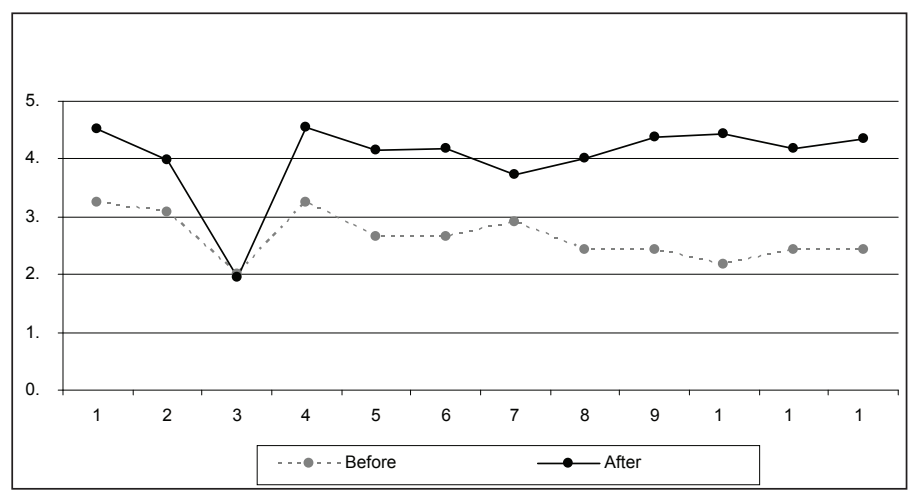

The differences described in the paragraph above have a tendency to increase. After privatization, there is a clear tendency to greater control by the board of directors over decision-making and an increasing demand of information about the management of the company (item 5). As well as these two aspects, which are the most valued by the control system, we also observe a greater need for qualitative information (item 8). Finally, the system allows managers to take greater part in the design of remuneration systems (item 10) and in the type of information given (item 12). Table 4 reflects the results of the Wilcoxon nonparametric test for each item.

\subsection{Performance evaluation systems}

\section{THE USE OF PERFormanCE MEASURES IN THE EVALUATION PROCESS}

Table 5 indicates that, in general, financial measures (item 1) are mostly used to measure managerial performance both before and after privatization. Nevertheless, after privatization, the use of quality measures (item 3 ) to evaluate managers is in second position (that is, they are used more). Likewise, as observed in Figure 4, there is also an increase in the widespread use of all the measures, which means an increase in the intensity of control mechanisms. 
Table 5: Use of performance measures in management evaluation

\begin{tabular}{|l|c|c|c|c|}
\cline { 3 - 5 } \multicolumn{1}{c|}{} & \multirow{2}{*}{ Before } & \multirow{2}{*}{ After } & \multicolumn{2}{c|}{ Wilcoxon test } \\
\cline { 4 - 5 } \multicolumn{1}{c|}{} & & & $Z$ & p-value \\
\hline 1. Financial measures & 2.34 & 3.93 & -1.83 & .07 \\
\hline 2. Commercial measures & 2.38 & 3.02 & -.92 & .36 \\
\hline 3. Quality measures & 1.58 & 3.90 & -1.83 & .07 \\
\hline 4. Innovation measures & 1.31 & 2.95 & -1.63 & .10 \\
\hline 5. Other performance measures & 2.00 & 4.02 & -1.60 & .11 \\
\hline
\end{tabular}

Figure 4: Average use of performance measures in management evaluation

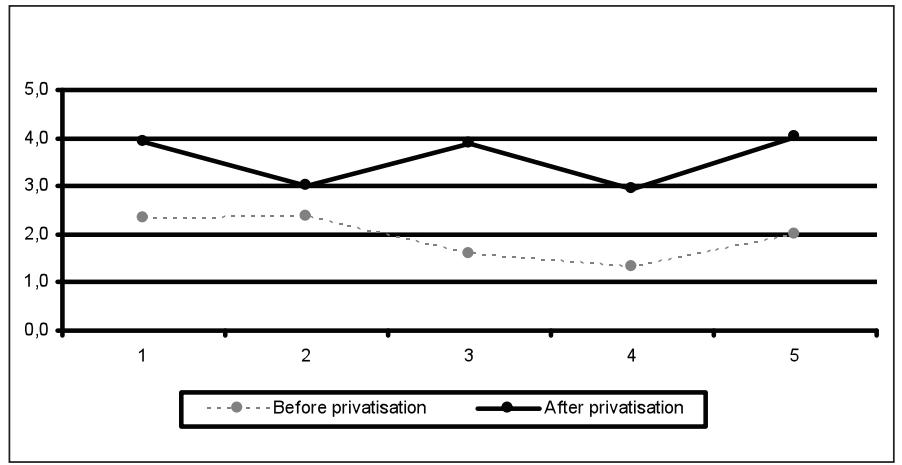

A closer look at the increasing use of control mechanisms and the most frequent measures used (financial measures: costs, profits and productivity) reveals the following: first, two-thirds of the responses indicated that cost measures were used more intensely after privatization, while one-third indicated no increase in level of use. As far as profits are concerned, $100 \%$ of the managers agreed that these increased after privatization. Finally, half of the managers indicated that productivity measures were used more intensely after privatization, whereas the other half considered that they were used to the same extent as in the pre-and post-privatization periods. Table 5 reflects the results of the Wilcoxon nonparametric test for each item.

\section{The USE of PERformanCE MEASURES in THE REMUNERATION PROCESS}

Likewise, the use of performance measures for management remuneration increases in intensity in the post-privatization period (Table 6 and Figure 5), which emphasizes the use of financial measures (item 1) and quality measures (item 3). Nevertheless, we should point out that after privatization the most significant increase is in "other performance measures" (item 5), which refers to 
external measures (benchmarking, stock exchange prices and others), and which doubles its value from an average of 2.08 to 4.02 .

Table 6: Use of performance measures in management remuneration

\begin{tabular}{|l|c|c|c|c|}
\cline { 4 - 5 } \multicolumn{1}{c|}{} & \multirow{2}{*}{ Before } & \multirow{2}{*}{ After } & \multicolumn{2}{c|}{ Wilcoxon test } \\
\cline { 4 - 5 } \multicolumn{1}{c|}{} & & & $Z$ & p-value \\
\hline 1. Financial measures & 2,21 & 3.93 & -1.83 & .07 \\
\hline 2. Commercial measures & 1.58 & 2.51 & -1.60 & .11 \\
\hline 3. Quality measures & 1.71 & 3.89 & -1.83 & .07 \\
\hline 4. Innovation measures & 1.19 & 2.90 & -1.60 & .11 \\
\hline 5. Other performance measures & 2.08 & 4.02 & -1.60 & .11 \\
\hline
\end{tabular}

Figure 5: Average use of performance measures in management remuneration

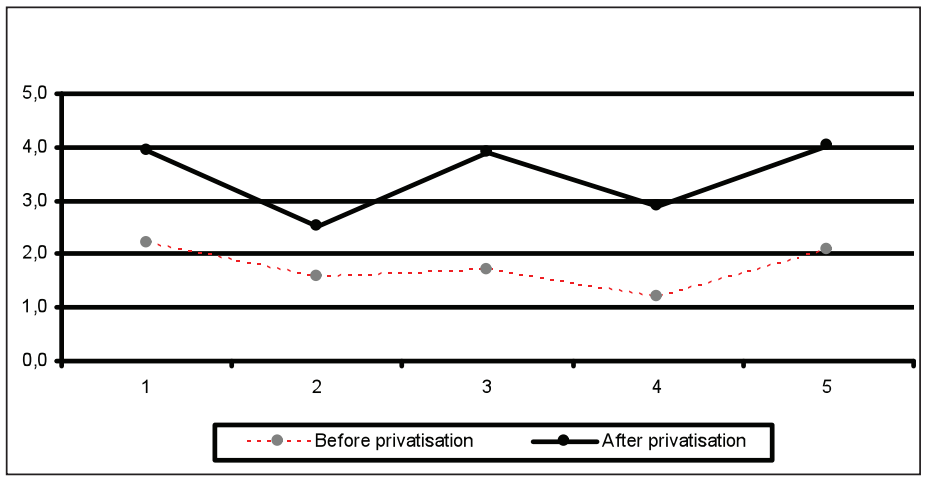

These behaviors can be analyzed in more detail by comparing the use of the most frequent measures (financial, quality and external) before and after privatization. More than $90 \%$ believed that financial measures were in greater use for setting managerial remuneration after privatization. Two-thirds of the managers polled believed that quality measures were used more frequently after privatization. And finally, more than $80 \%$ believed that "other performance measures" (external measures) were used more after privatization. Table 6 reflects the results of the Wilcoxon non-parametric test for each item.

\section{Conclusion}

In this research, we compare corporate governance and firm strategy before and after privatization. We also compare control and performance evaluation systems in the pre- and post-privatization periods, and try to understand them 
in relation to previous variables (corporate governance and firm strategy). Although privatization has been the object of a considerable amount of research, most studies have adopted a macroeconomic or political approach. Our study, however, adopted an organization-level approach. Our research makes some important contributions to the previous literature.

First, we predicted that privatization would cause a change in owners' interests, with subsequent changes in the board of directors to support the new interests of the new ownership. From an agency perspective, more independent boards (removed from the political arena) should appear after privatization. However, our empirical findings show that the board of directors did not become more independent after privatization. In fact, the data suggest that privatization does not imply a change in terms of who takes on the chairman and CEO positions in a privatized company, because these positions are occupied by the same person.

On the basis of the results obtained from the boards of directors, we also observed that privatization does not necessarily increase the number of outsiders. This may suggest that in Spain, unlike other countries, boards of directors are not open to external members despite corporate governance recommendations to have outsiders on boards. Although there was no variation in the percentages of outsiders/insiders, what should be highlighted here is the concentration of shares after privatization. Indeed, after privatization in most of the companies analyzed financial institutions with representatives on the board had more than $5 \%$ capital,. In these firms, these directors had considerable influence for some years, reaching almost .5 in one of the companies studied in one specific year.

Second, we conclude that there is no change in strategy in the companies analyzed as a consequence of the change in ownership. One possible explanation for this is that the lack of significant changes in the board automatically meant that that there was a corresponding lack of change in strategic orientation. Nevertheless, in spite of the lack of change in company strategies, we observed that privatized companies put greater emphasis on factors related to customer services, innovation and costs.

Thirdly, as far as the supervision function - management evaluation - of the board of directors is concerned, we observed that after privatization there is a clear tendency to greater control of strategic decisions, which is consistent with the reinforcement of strategic factors mentioned above. In addition, there is a significant increase in the frequency of requests for information about managers - among other variables - probably as a mechanism to exert this control. We should also point out that these control systems are the result of negotiation between top managers and the board of directors. In general, after privatization 
the monitoring function exercised by the board of directors over managers increases, which leads to greater efforts to capture strategic decisions made by the management team.

Finally, there were also significant changes in both periods (pre- and postprivatization) in the measures of performance used to evaluate the managers. Like the factors of competitiveness, the measures that seem to be most important after privatization are those taken on issues of finance and quality. The performance measures used to reward managers require such external measures as benchmarking and stock exchange price (which were used much less before privatization). Thus, this multi-case study not only confirms the changes in measures of performance, but also outlines the direction of the changes that are expected in the use of performance measures after the process of privatization.

Our findings also confirm that the governance structures, with the presence of blockholders (especially financial institutions), helped to align the managers' behavior with the interests of the new ownership through control and performance evaluation systems, thus revealing the relations between the macro-organizational level (the firm's governance structure) and the microorganizational level (performance evaluation systems).

This research has some limitations. Firstly, the effects of corporate governance on control and performance evaluation systems need to be analyzed, but the influence of these changes on firm efficiency after privatization also needs to be evaluated. Secondly, it would also be interesting to evaluate how different types of blockholder can influence the effects of privatization.

\section{References}

Aguilera, R. (2005). “Corporate governance and employment relations: Spain in the context of Western Europe". In H.P. Gospel and A. Pendleton (eds.), Corporate governance and labour management: an international comparison, Oxford University Press, 197-225.

Baysinger, B. and Butler H. (1985). "Corporate governance and the Board of Directors: performance effects of changes in Board composition". Journal of Law, Economics, and Organization, $1: 101-124$.

Cabeza, L. and Gómez, S. (2007). "Governance and Performance of Spanish Privatised Companies". Corporate Governance: An international Review, 15 (4): 503-519.

Carpenter, M. A. and Westphal, J. D. (2001). "The strategic context of external ties: examining the impact of director appointments on board 
involvement in strategic decision making". Academy of Management Journal, $44(4): 639-60$.

Coles, J. W.; McWilliams, V. B., and Sen, N. (2001). "An examination of the relationship of governance mechanisms to performance". Journal of Management, 27 (1): 23-50.

Cragg, M. and Dyck, I. (2000). "Executive Pay and UK Privatization: The Demise of "One Country, Two Systems". Journal of Business Research, 47:3-18.

Cuervo, A. and Villalonga, B. (2000). "Explaining the variance in the performance effects of privatization". Academy of Management Journal, 25: 581-590.

Cuevas, G.; Alvarez-Dardet, C. and Valle, R. (2007). "Incentives Management During Privatization: An Agency Perspective". Journal of Management Studies, 44 (4): 536-560.

Dess, G. and Davis, P. (1984)."Porter's Generic Strategies as Determinants of Strategic Group Membership and Organizational Performance". Academy of Management Journal, 27 (2): 467-488.

Donaldson, L. and Preston, L. (1995). "A Stakeholder Theory of the Corporation: Concepts, Evidence, and Implications". Academy of Management Review, 20 (1): 65-91.

Eisenhardt, K. M. (1989). "Agency Theory: An Assessment and Review". Academy of Management Review, 14 (1), 57-74.

Fama, E. and Jensen, M. (1983). "Separation of Ownership and Control". Journal of Law and Economics, 26: 301-325.

Fernández, C. and Arrondo, R. (2005). "Alternative Internal Controls as Substitutes of the Board of Directors". Corporate Governance: An international Review, 13 (6): 856-866.

Giancreco, A. and R. Peccei (2005). "The Nature and Antecedents of Middle Manager Resistance to Change: Evidence from an Italian Context". International Journal of Human Resource Management, 16 (10): 1812-1829.

Heracleous, L. (2001). "What is the Impact of Corporate Governance on Organisational Performance?". Corporate Governance: An international Review, 9 (3): 165-173.

Hsu, H. (2010). "The relationship between board characteristics and financial performance: An empirical study of United States Initial Public Offerings". International Journal of Management, 27 (2): 332-342.

Jensen, M. and Meckling, W. (1976). "Theory of the Company: Managerial Behaviour, Agency Costs, and Ownership Structure". Journal of Financial Economics, 3: 305-60. 
Kim, Y. (2007). "The Proportion and Social Capital of Outside Directors and Their Impact on Company Value: Evidence from Korea". Corporate Governance: An International Review, 15 (6): 1168-1176.

Michael, S. C. and Pearce, J. A., II. (2004). "Choosing Constraints as a Third Solution to Agency". Journal of Management Studies, 41 (7): 1171-1197.

Nestor, S. (2005). "Falling Between the Cracks: Privatization and Corporate Governance in the European Telecom Industry". Corporate Governance: An international Review, 13 (2): 137-155.

Okpara, J., and WynN, P. (2008). "The impact of ethical climate on job satisfaction, and commitment in Nigeria: Implications for management development". Journal of Management Development, 27 (9)ः 935-950.

Romero, A.M. (2006). "Privatization and the Entrepreneurial Corporate Initiative". $16^{\text {th }}$ ACEDE National Congress, September, Valencia.

Rourke, F. (1984). Bureaucracy, Politics, and Public Policy. Boston: Little, Brown (3d ed.).

Rutherford, A. M. and Buchholtz, A. K. (2007). "Investigating the Relationship Between Board Characteristics and Board Information". Corporate Governance: An international Review, 15 (4):576-584.

Schröder, P. (2003). "Insider Privatization and Restructuring Incentives". Economics of Planning, 36: 333-49.

Scott, T, and P. Tiessen (1999). "Performance measurement and managerial teams". Accounting, Organizations and Society, 24: 263-285.

Shleifer, A. and Vishny, R. (1986). "Large Shareholders and Corporate Control". Journal of Political Economy, 94 (3): 461-488.

Siegel, S. and Castellan, J. (1988) Nonparametric Statistics for the Behavioural Sciences. New York: McGraw-Hill.

Tan, J.J. and Litschert, R.J. (1994). "Environment-Strategy Relationship and its Performance Implications: An Empirical study of the Chinese Electronics Industry". Strategic Management Journal, 15 (1): 1-20.

Tosi, H. and Gomez-Mejia, L. (1989) "The De-coupling of CEO Pay and Performance: An Agency Theory Perspective". Administrative Science Quarterly, 34: 169-189.

Tosi, H. and Gomez-Mejía, L. (1994). "CEO compensation monitoring and company performance. Academy of Management Journal, 37: 1002-1018.

Tribo, J. A.; Berrone, P. and Surroca, J. (2007). "Do the Type and Number of Block-holders Influence R\&D Investments? New Evidence from Spain". Corporate Governance: An international Review, 15 (5): 828-842. 
White, RE. and Hammermesh, RG. (1981)."Toward a model of business unit performance: An integrative approach". Academy of Management Review, 6: 213-223.

Whitley, R (1999). "Firms, institutions and management control: the comparative analysis of coordination and control systems". Accounting, Organizations and Society, 24: 507-524.

Yarrow, G. (1986)."Privatization in theory and practice”. Economic Policy, 1 (2): 324-377.

YIN, R. (1994). Case Study Research: Design and Methods. Newbury Park, CA: Sage. (2nd ed.).

Yoshikawa, T. and Phan, P.H. (2005)."The effects of ownership and capital structure on board composition and strategic diversification in Japanese corporations". Corporate Governance, 13 (2):303-312.

Young, G.; Stedham, Y. and Beekun, R. (2000). "Boards of Directors and the Adoption of a CEO Performance Evaluation Process: Agency and Institutional-theory Perspectives". Journal of Management Studies, 37 (2): 277-295.

Zahra, S.A. and Hansen, C. (2000). "Privatization, Entrepreneurship and Global Competitiveness in the 21st century". Competitiveness Review, 10 (1): 83-103.

Zahra, S.; Ireland, R.; Gutierrez, I. and Hitt, M. (2000). “Privatization and Entrepreneurial Transformation: Emerging Issues and a Future Research Agenda". Academy of Management Journal, 25: 509-524.

Zahra, S. A.; Neubaum, D. O. and Huse, M. (2000). "Entrepreneurship in medium size companies: exploring the effects of ownership and governance systems". Journal of Management, 26 (5): 947-976. 